induced deterioration in functioning. It seems most likely, however, that the major factor responsible for the improvement was better seizure control.

In conclusion, the results of the short term part of the study suggest that treatment with vigabatrin did not produce significant cognitive impairment. Patients reported early sedation, but this had disappeared by the 12th week of treatment. Longer term follow up allowed the identification of a further small improvement in overall performance. The sustained reduction in seizure frequency may have contributed to its development. From the practical viewpoint, phased introduction of vigabatrin seems a prudent policy to permit tolerance to subjective sedation during early treatment.

Our grateful thanks go to Moya Dewar for expert secretarial assistance and to Marion Merrell Dow for supplying the drug and placebo and for financial support.

1 Editorial. Vigabatrin. Lancet 1989;1:532-3.

2 Mumford JP, Dam M. Meta-analysis of European placebo-controlled studies of vigabatrin in drug-resistant epilepsy. Br f Clin Pharmacol 1989;27(Suppl 1):S101-7.

3 Ring HA, Heller AJ, Farr IN, Reynolds EH. Vigabatrin rational treatment for chronic epilepsy. If Neurol Neurosurg Psychiatry 1990;53:1051-5.

4 Grant SM, Heel RC. Vigabatrin. Drugs 1991;41:889-926.

5 Michelucci R, Tassinari CA. Response to vigabatrin in relation to seizure type. $\mathrm{Br} \mathcal{F}$ Clin Pharmacol 1989;27(Suppl 1):S119-24.

6 Pedersen SA, Klosterkov P, Gram L, Dam M. Long-term study of gamma-vinyl GABA in the treatment of epilepsy. Acta Neurol Scand 1985;72:295-8

7 Sivenius MR, Ylinen A, Murros K, Matkainen $R_{\text {, }}$ Sivenius MR, Ylinen A, Murros $\mathrm{K}$, Matkainen $\mathbf{R}$,
Riekkinen P. Double-blind dose reduction study of vigabiekkinen P. Double-blind dose reduction study of vigabatrin in

8 Browne TR, Mattson RH, Penry JK, et al. Vigabatrin for refractory complex partial seizures: multicenter single blind study with long-term follow-up. Neurology 1987; 37:184-9.

9 Cocito L, Maffini M, Perfumo P, Roncallo F, Loeb C.
Vigabatrin in complex partial seizures: a long-term study. Epilepsy Res 1989;3:160-6.

10 Remy C, Beaumont D. Efficacy and safety of vigabatrin in the long-term treatment of refractory epilepsy. $\mathrm{Br} \mathcal{F} \mathrm{Clin}$ Pharmacol 1989;27(Suppl 1):S125-9.

11 Tartara A, Manni R, Galimberti CA, Mumford JP, Iudice A, Perucca E. Vigabatrin in the treatment of epilepsy: a long-term follow-up study. F Neurol Neurosurg Psychiatry $1989 ; 52: 467-71$

12 Dam M. Long-term evaluation of vigabatrin (gamma vinyl GABA) in epilepsy. Epilepsia 1989;30(Suppl 3):S26-30.

13 Sander JW, Trevisol-Bittencourt PC, Hart YM, Shorvon SD. Evaluation of vigabatrin as an add-on drug in the management of severe epilepsy. $\mathcal{f}$ Neurol Neurosurg Psychiatry 1990;53:1008-10.

14 Reynolds EH, Ring HA, Farr IN, Heller AJ, Elwes RD. Open, double-blind and long-term study of vigabatrin in chronic epilepsy. Epilepsia 1991;32:530-8.

15 Sivenius J, Ylinen A, Murros K, Mumford JP, Reikkinen PJ. Vigabatrin in drug-resistant partial epilepsy: a 5-year PJ. Vigabatrin in drug-resistant partial epileps
follow-up study. Neurology 1991;41:562-5.

16 Butler WH. The neuropathology of vigabatrin. Epilepsia 1989;30(Suppl 3):S15-17.

17 Gibson JP, Yarrington JT, Loudy DE, Gerbig CG, Hurst GH, Newberne JW. Chronic toxicity studies with vigabatrin, a GABA-transaminase inhibitor. Toxicol Pathol 1990;18:225-38

18 Agnosti T, Yasargil G, Egil M, Wieser HG, Wiestler OD. Neuropathology of a human hippocampus following long-term treatment with vigabatrin: lack of microvacuoles. Epilepsy Res 1990;6:166-70

19 Cannon DJ, Butler WH, Mumford JP, Lewis PJ. Neuropathologic findings in patients receiving longterm vigabatrin for chronic intractable epilepsy. $f$ Child term vigabatrin for chronic intract

20 McGuire AM, Duncan JS, Trimble MR. Effect of vigabatrin on cognitive function and mood when used as addon therapy in patients with intractable epilepsy Epilepsia 1992;33:128-34.

21 Gillham RA, Williams N, Wiedmann K, Butler E, Larkin JG, Brodie MJ. Concentration-effect relationships with carbamazepine and its epoxide on psychomotor and cognitive function in epileptic patients. $f$ Neurol Neurosurg Psychiatry 1988;51:929-33.

22 Gillham $R$, Williams $N$, Wiedmann $K$, Butler $E$, Larkin JG, Brodie MJ. Cognitive function in adult epileptic patients established on anticonvulsant monotherapy. Epilepsy Res 1990;7:219-25.

23 Gillham RA, Read CL McKee PJW, Larkin JG, Brodie MJ. Cognitive function in adult epileptic patients on MJ. Cognitive function in adult epileptic patients on

24 Brodie MJ, McKee PJW. Vigabatrin and psychosis. Lancet 1990;335:1279.

25 Brodie MJ, McPhail E, Macphee GJA, Larkin JG, Gray JMB. Psychomotor impairment and anticonvulsant therapy in adult epileptic patients. Eur $f$ Clin Pharmacol 1987;31:655-60.

\section{Historical description of primary writer's tremor}

Tremor elicited by writing may be a feature of several neurological diseases. In rare occasions it presents as a unique symptom, and its independent nosological identity is frequently discussed. In other patients it is combined with essential tremor ${ }^{1}$ or focal dystonia. ${ }^{2}$ The modern description of this entity corresponds to Rothwell, Traub and Marsden. ${ }^{3}$ However, we have encountered a description by Grisolle ${ }^{4}$ in 1848 that exactly resembles writer's tremor: "The affection consists of a particular tremor of the right hand fingers only observed when writing, and absent in all other circumstance. The patient is able to cut the pen and hold it with his fingers a long while, as if he were to write; he is able to wash himself, shave and play piano without difficulty. But as soon as he begins to write he is affected by tremor. When writing is interrupted, tremor ceases. On many ocasions patients do not experience discomfort or pain. In others, these do exist."

"This affection seems to develop slowly; until now it has only been observed in males and all were above the age of 30."

"Alcohol spirits, moral affections and seminal losses are all believed to increase the tremor. The symptoms have never been ascribed to a certain disease; therefore, it has been compared with chorea."
Although this description probably also includes patients with writer's cramp, the mention of absence of uncomfortable or painful sensations and male predominance refers, undoubtedly, to primary writer's tremor.

$$
\begin{array}{r}
\text { J CASTILLO } \\
\text { FMARTINEZ } \\
\text { A GONZÁLEZ-QUINTELA } \\
\text { M NOYA } \\
\text { Servicio de Neurologia, } \\
\text { Hospital General de Galicia-Clinico Universitario, }
\end{array}
$$
Santiago de Compostela, Spain

Correspondence to: Professor J Castillo, Servicio de Neurología, Hospital General de Galicia-Clínico Universitario, Santiago de Compostela, Spain.

1 Kachi T, Rothwell JC, Cowan JMA, Marsden CD. Writing tremor: its relationship to benign essential tremor. $f$ Neurol Neurosurg Psychiatry 1985;48:545-50. 2 Elble RJ, Moody C, Higgins C. Primary writing tremor. A form of focal dystonia? Mov Disord 1990;5:118-26.

3 Rothwell JC, Traub MM, Marsden CD. Primary writing tremor. $f$ Neurol Neurosurg Psychiatry 1979;42: 1106-14.

4 Grisolle A. Tratado de Patologia Interna. Tomo sesto. De las neurosis. Madrid: Imprenta de Francisco Andrés y Compañía, 1848:93-4. 